\title{
Mechanisms of Developmental Toxicity of Dioxins and Related Compounds
}

\author{
Wataru Yoshioka ${ }^{*}+$ (i) and Chiharu Tohyama $\neq$ (1) \\ Laboratory of Environmental Health Sciences, Center for Disease Biology and Integrative Medicine, \\ Graduate School of Medicine, The University of Tokyo, Tokyo 113-0033, Japan; tohyamac-tky@umin.org \\ * Correspondence: yoshioka-w@umin.ac.jp; Tel.: +81-3-5841-1434 \\ † Present address: Department of Public Health \& Environmental Medicine, The Jikei University School of \\ Medicine, Tokyo 105-8461, Japan. \\ $\ddagger$ Present address: Environmental Biology Laboratory, Faculty of Medicine, University of Tsukuba, \\ Tsukuba 305-8575, Japan.
}

Received: 13 December 2018; Accepted: 30 January 2019; Published: 31 January 2019

\begin{abstract}
Dioxins and related compounds induce morphological abnormalities in developing animals in an aryl hydrocarbon receptor (AhR)-dependent manner. Here we review the studies in which 2,3,7,8-tetrachlorodibenzo- $p$-dioxin (TCDD) is used as a prototypical compound to elucidate the pathogenesis of morphological abnormalities. TCDD-induced cleft palate in fetal mice involves a delay in palatogenesis and dissociation of fused palate shelves. TCDD-induced hydronephrosis, once considered to be caused by the anatomical obstruction of the ureter, is now separated into TCDD-induced obstructive and non-obstructive hydronephrosis, which develops during fetal and neonatal periods, respectively. In the latter, a prostaglandin $\mathrm{E}_{2}$ synthesis pathway and urine concentration system are involved. TCDD-induced abnormal development of prostate involves agenesis of the ventral lobe. A suggested mechanism is that AhR activation in the urogenital sinus mesenchyme by TCDD modulates the wingless-type MMTV integration site family (WNT)/ $\beta$-catenin signaling cascade to interfere with budding from urogenital sinus epithelium. TCDD exposure to zebrafish embryos induces loss of epicardium progenitor cells and heart malformation. AHR2-dependent downregulation of Sox9b expression in cardiomyocytes is a suggested underlying mechanism. TCDD-induced craniofacial malformation in zebrafish is considered to result from the AHR2-dependent reduction in SRY-box 9b (SOX9b), probably partly via the noncoding RNA $\operatorname{sincR}$, resulting in the underdevelopment of chondrocytes and cartilage.
\end{abstract}

Keywords: dioxin; TCDD; malformation; terata; cleft palate; hydronephrosis; prostate; heart; jaw

\section{Introduction}

Dioxins and related compounds are a group of structurally related chemicals composed of two coplanar benzene rings. These compounds induce a similar spectrum of toxicity phenotypes with a wide degree of potency. Each chemical is assigned a toxic equivalency factor (TEF) relative to 2,3,7,8-tetrachlorodibenzo- $p$-dioxin (TCDD), the most toxic compound among this group of chemicals [1]. In experimental studies on toxicity mechanisms, TCDD has been used as a prototypical compound, with teratogenicity representing a sensitive indicator of TCDD toxicity in experimental animals [2]. Aryl hydrocarbon receptor (AhR, or dioxin receptor), a ligand-activated transcription factor (see reviews [3,4] for molecular biology of $\mathrm{AhR}$ and history), is indispensable for the manifestation of TCDD teratogenicity. This pivotal role for AhR was demonstrated using AhR-null mice $[5,6]$ and AHR2-null zebrafish [7]. The lack of teratogenicity in the absence of AhR indicates that intrinsic factors inadequately regulated by TCDD-activated AhR are involved in the pathogenesis. Downstream 
of AhR signaling, putative candidate molecules have been indicated to distinctly induce various toxicity phenotypes [8]. The present review focuses on the recent progress reported on the mechanisms of developmental toxicity, in terms of teratogenicity, malformation, and morphological changes in laboratory animals exposed to TCDD.

\section{Cleft Palate}

\subsection{Characterization of TCDD-Induced Cleft Palate}

Cleft lip and cleft palate are among the most common birth defects in humans $[9,10]$. Pathogenesis of isolated cleft palate (cleft palate only without cleft lip) and cleft lip accompanied with or without cleft palate are thought to result from different mechanisms based on observations that these two conditions do not segregate in the same family. In hamsters, mice, and rats, TCDD administration to pregnant animals induces cleft palate in fetuses [11-13]. TCDD was confirmed to induce cleft palates but not cleft lips in mice [14,15].

The susceptibility peak period for the onset of cleft palate is around gestational days (GDs) 9-12 in ICR and C57BL/ 6 strains of mice [14-17]. In a report by Couture et al. [16], oral administration of TCDD at a dose of $24 \mu \mathrm{g} / \mathrm{kg}$ to pregnant C57BL/ 6 mice on GDs 8 and 12 results in $93 \%$ and $100 \%$ incidence, respectively, when the fetuses were examined on GD 18. In contrast, TCDD administration on GDs 6 and 14 results in $40 \%$ and $0 \%$ incidence, respectively. The incidence in the earlier period is low to modest $(0-40 \%)$ at a TCDD dose of up to $40 \mu \mathrm{g} / \mathrm{kg}[14,16,17]$, whereas it is high $(100 \%)$ at a dose of $80 \mu \mathrm{g} / \mathrm{kg}$ [17], suggesting that the higher dose cancels the apparent window of susceptibility in the earlier period. The lower or no incidence in later periods irrespective of the lower or higher dose [14-17] is considered to be related to the timing of palatogenesis completion [18].

Palatogenesis is considered to comprise several steps: growth, shelf elevation, contact, and fusion [19] (see review [20] for detailed mechanisms). The timing of organogenesis has been studied in detail in mouse fetuses [21]: in the normal development, palate shelves elevate from GD 14.0 to GD 14.25 and fuse completely by GD 14.5 [15,21]. TCDD exposure delays the elevation of shelves by one day, reduces the fusion efficiency of shelves on GD 14-16, and induces cleft palate on GD 17-18 [21-24]. Of note, even successfully fused palate shelves are suggested to be finally dissociated to develop cleft palate in TCDD-exposed fetuses $[15,22,23]$; these fusion rates in fetuses exposed to TCDD at a dose of $40 \mu \mathrm{g} / \mathrm{kg}$ were $17.5 \%$ and $0 \%$ on GD15 and GD18, respectively [22]. These findings suggest that TCDD not only perturbs the palatogenesis steps but also induces post-fusional rupture of the palate [25]. In addition, mouse embryos with narrower skulls owing to exencephaly are resistant to TCDD-induced cleft palate [24], which indicates the importance of balance in the development of the palatal shelves and the skull size.

\subsection{Molecular Basis of TCDD-Induced Cleft Palate Onset}

Genetic ablation of AhR results in the complete suppression of TCDD-induced cleft palate [5], demonstrating an indispensable role of $A h R$ in the pathogenesis. AhR promoter activity is high in epithelial cells and weak in mesenchymal cells of palatal shelves [5]. Furthermore, antibody immunoreactivity against $A h R$ is found in bone and muscle tissues in the palate [23]. Importantly, AhR in the medial edge epithelia (MEE) in palatal shelves are indicated to be more strongly expressed before rather than after the fusion of palatal shelves [5]. Furthermore, MEE in TCDD-exposed fetuses are covered with a monolayer of epithelial cells [21] with filopodia extensions reduced in number and length $[21,26]$, whereas in the vehicle-control fetuses, they are covered with 2-3 layers of epithelial cells with filopodia extensions $[21,26]$. These findings are consistent with previous observations that TCDD inhibits proliferation of cells in palatal shelves [24] and with the interpretation that TCDD perturbs programmed cell death in MEE [27,28].

Thomae et al. [26] utilized ex vivo culture of palatal shelves harvested from mouse fetuses to show that TCDD-exposed palatal shelves did not fuse, but that control palatal shelves did. In addition, 
TCDD exposure ex vivo reduced filopodia extension in MEE similarly to that in vivo. On the other hand, the layer structure of epithelium exposed to TCDD ex vivo [26] appears to be thicker than that in vivo [21], and potentially important paracrine factors could be absent in the ex vivo culture. In the ex vivo experiments, the treatment of the palatal shelves with transforming growth factor- $\beta 3$ (TGF- $\beta 3$ ) restored palatal fusion in the presence of TCDD [26]. This finding and the central role of TGF- $\beta 3$ in the fusion process of palatogenesis [20] suggest that insufficient amounts of TGF- $\beta 3$ are involved in TCDD-induced cleft palate onset. However, because TGF- $\beta 3$ expression is upregulated at mRNA $[29,30]$ and protein levels [30] in the palate of TCDD-exposed fetuses, this hypothesis does not seem to be valid. This inconsistency might be explained by the differences in the ex vivo and in vivo experimental systems.

Furthermore, several genes and molecules are suggested to be associated with TCDD-induced cleft palate. A plausible candidate, fibroblast growth factor receptor 1 (FGFR1), is expressed in the frontal epithelia before shelf elevation, and FGFR1 mutations are often associated with cleft palate. Disappearance of FGFR1 was observed in TCDD-exposed shelves on GD 15.5 [21]. The expression of the osteogenesis markers Runx2 and osteopontin (OPN) is decreased in the palatal bone wherein AhR is strongly expressed on GD16 [23]. The expression of the myogenesis markers MyoD and desmin is diminished in TCDD-exposed palatal shelves on GD 16 [21]. Higher level in the expression of epidermal growth factor (EGFR) and the associated decrease in E-cadherin, $\alpha$-catenin, and $\beta$-catenin expression in TCDD-exposed palatal shelves may be involved in the onset of TCDD-induced cleft palate [22,27]. Burns et al. [31] pointed out the possibility that reduction in the expression of SRY-box 9 (Sox9) may be involved in TCDD-induced cleft palate based on the similarities in development as well as gene expression patterns between the mouse palate and the zebrafish parasphenoid. Finally, although expression of a number of genes is reportedly altered in the palate exposed to TCDD, the toxicological significance of such alterations remains to be clarified.

\section{Hydronephrosis}

In humans, hydronephrosis is found in $1.5-3.3 \%$ of all autopsies [32] and in $1-5 \%$ of pregnancies on antenatal ultrasonography $[33,34]$. The major cause of hydronephrosis is the anatomical obstruction of the urinary tract from the kidney to the bladder via the ureter. Any obstruction of the urinary flow at any point along the urinary tract causing retention of urine will increase the retrograde hydrostatic pressure, leading to the destruction of kidney parenchyma and hydronephrosis. In mice, more than 100 genes are associated with hydronephrosis $[35,36]$, and a mutation in or lack of any one of these genes results in hydronephrosis development. They encode a wide variety of proteins, including components of the renin-angiotensin system, ligands and receptors in signaling cascades, structural proteins of the ureter, extracellular matrix proteins, and transporters. Such a variety suggests that the urinary tract requires multiple mechanisms to perform urine propelling and to maintain an adequate balance of urine production and excretion and that the loss of any one of these mechanisms results in the development of hydronephrosis. One of these mechanisms is related to polyuria. A mutation in or lack of genes, such as those for aquaporin 2 (AQP2), Barttin, sodium-potassium-chloride cotransporter 2 (NKCC2), or V2 vasopressin receptor, results in polyuria and hydronephrosis [37-42], and polyuria can overwhelm the urine excretion capacity to induce hydronephrosis. Herein, we review studies on the toxicological basis of the TCDD-induced hydronephrosis in mice and rats.

\subsection{TCDD-Induced Hydronephrosis}

Courtney and Moore [13] found that administration of TCDD to pregnant mice or rats induces kidney abnormalities including hydronephrosis in fetuses. Moore et al. [43] further characterized TCDD-induced hydronephrosis. The oral administration of TCDD at doses of $1-3 \mu \mathrm{g} / \mathrm{kg}$ to pregnant C57BL / 6 mice on GD 10 or from GD 10 to GD 13 induces a size reduction or the loss of the renal papilla and the dilation of renal calyces and renal pelvis in the fetus on GD 18. In addition, oral dosing of TCDD of 1,3 , or $10 \mu \mathrm{g} / \mathrm{kg}$ to mothers at parturition induces hydronephrosis in their pups on postnatal 
day (PND) 14, revealing that TCDD exposure in the neonatal period induces hydronephrosis. In a four-way cross fostering study that comprises four groups of mother/pup pairs formed at the time of parturition [(1) non-exposed mother/non-exposed pup, (2) non-exposed mother/exposed pup, (3) exposed mother/non-exposed pup, and (4) exposed mother/exposed pup], it was demonstrated that pups are more susceptible to TCDD-induced hydronephrosis in the neonatal period than in the fetal period [43]. This observation in mice was extended to Holtzman rats [44]. These studies clarified that TCDD induces hydronephrosis in fetal and neonatal periods of rodents and that the latter is more sensitive than the former.

\subsection{Characterization of TCDD-Induced Neonatal Hydronephrosis}

Couture-Haws et al. [45] determined a critical window for TCDD-induced neonatal hydronephrosis (TiNH). When mothers of C57BL/6N mice were orally administered TCDD $(9 \mu \mathrm{g} / \mathrm{kg})$ on PND 1, their pups developed hydronephrosis by PND 26 with an incidence of $89 \%$. When exposed on PND 4, the incidence dropped to $41 \%$. When exposed on PND 8 or 14, the incidence was similar to that in vehicle-control mice. Thus, TiNH displays a narrow critical window confined to a few days after parturition.

TiNH in mice is not accompanied with anatomical obstruction; the histological examination of ureter serial sections revealed no obstruction from renal pelvis to bladder in the afflicted pups [6]. Lack of obstruction at the renal pelvis, the proximal portion of the ureter, and the ureter insertion site into the bladder is reported in other studies [43,46]. Furthermore, ink-injection into the pelvicalyceal space resulted in dyeing of the bladder at similar hydrostatic pressure in affected pups and vehicle-control pups [6]. The microscopic observation of ureteric peristalsis, which propels urine from kidney to bladder, revealed no apparent abnormality in the affected pups [46]. While these studies did not find any obstruction, TiNH was found to be accompanied with an increase in urine volume [46]. TCDD-exposed pups had greater volumes of urine in their bladder both at daytime and at night. Suppression of urine production by an antidiuretic agent resulted in reduction of the urine volume as well as of the incidence and severity of hydronephrosis. These studies revealed that TiNH is of a non-obstructive type and is associated with an increase in urine volume.

\subsection{Molecular Targets Linking TCDD Exposure and TiNH}

AhR is required for the onset of TiNH [6]. Additional factors responsible for TiNH are cyclooxygenase-2 (COX-2, coded by Ptges 2 ) and microsomal prostaglandin synthase-1 (mPGES-1, coded by Ptges). COX-2 converts arachidonic acid (AA) to prostaglandin $\mathrm{H}_{2}\left(\mathrm{PGH}_{2}\right)$, and mPGES-1 transforms $\mathrm{PGH}_{2}$ to prostaglandin $\mathrm{E}_{2}\left(\mathrm{PGE}_{2}\right)$. TCDD exposure increases the expression of COX-2 and mPGES-1 in the kidney and the excretion of $\mathrm{PGE}_{2}$ from the kidney $[6,47]$. Pharmacological inhibition of COX-2 [6] or genetic ablation of mPGES-1 [47] suppresses the TCDD-induced increase of $\mathrm{PGE}_{2}$ excretion and completely blocks TiNH onset. Therefore, the COX-2/mPGES-1/PGE 2 pathway plays an essential role in the onset of TiNH. An upstream regulator acting as the predominant regulator of this pathway in TiNH is cytosolic phospholipase $\mathrm{A}_{2} \alpha\left(\mathrm{CPLA}_{2} \alpha\right.$, coded by Pla2g4a), which converts phospholipids into AA. The genetic ablation of $\mathrm{CPLA}_{2} \alpha$ results in marked suppression of TCDD-induced increase in the expression of COX-2 and mPGES-1 in the kidney and excretion of $\mathrm{PGE}_{2}$, and subsequently in hydronephrosis onset [48]. In vitro studies support the role of ${ }_{C P L A} \alpha$ : TCDD-induced increase in COX-2 expression is suppressed by pharmacological inhibition or siRNA-mediated knockdown of $\mathrm{CPLA}_{2} \alpha$, and AA plays a role in increasing COX-2 expression [49,50]. Furthermore, $\mathrm{CPLA}_{2} \alpha$ is transcriptionally [51,52] and/or enzymatically $[49,50]$ upregulated by TCDD via AhR. Of note, TCDD is suggested to impair milk production in dams [53] owing to defects in the mammary glands [53-55]. This raises the possibility that TCDD-induced impairment in lactation influences TiNH. However, the potential influence seems to be too small to be detected in pups lacking one of essential factors such as AhR and mPGES-1 [6,47]. 
Interestingly, while TCDD-induced upregulation of the COX-2/mPGES-1/PGE 2 pathway depends on $\mathrm{CPLA}_{2} \alpha$, TCDD-induced increase in the expression of other genes, such as those coding for cytochrome P450 1A1 (CYP1A1), AhR repressor (AhRR), and insulin-like growth factor binding protein 1 (IGFBP-1), does not depend on $\mathrm{CPLA}_{2} \alpha$ in the pup kidneys [48]. These cPLA $\mathrm{A}_{2} \alpha$-independent genes are known as direct targets of transactivation capacity of AhR [56,57]. Detailed mechanism(s) for the $\mathrm{CPLA}_{2} \alpha$-dependent pathway are not yet elucidated, but several possibilities are conceivable. $\mathrm{CPLA}_{2} \alpha$ may be directly upregulated by transactivation capacity of AhR. Alternatively, $\mathrm{CPLA}_{2} \alpha$ may be

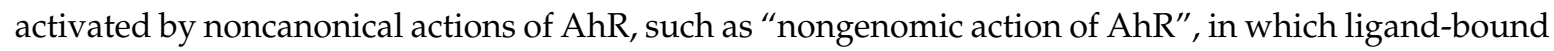
AhR rapidly induces calcium signaling in the cytoplasm to induce activation of $\mathrm{CPLA}_{2} \alpha$ [58].

Signaling downstream of $\mathrm{PGE}_{2}$ leading to TiNH remains to be elucidated. A plausible mechanism is that increased $\mathrm{PGE}_{2}$ in the renal tubules interferes with the water reabsorption system [59-61], resulting in a decrease in water permeability $[60,61]$ to produce diluted urine $[46,62]$; consequently, the increased urine volume [46] overwhelms the ureter propelling capacity and causes backpressure in the kidney pelvicalyceal space.

\subsection{Molecular Basis of the TiNH Window and TiNH Susceptibility}

Assessing developmental stage-specific onset of toxicity phenotypes is challenging but essential in the risk assessment of TCDD. Based on the understanding of the molecular mechanism of TiNH, neonatal stage-specific factors were researched [46]. In adult mice, which are resistant to TCDD-induced hydronephrosis [45], TCDD does not induce upregulation of COX-2 or mPGES-1 expression, neither does it increase urine volume. However, TCDD induces renal expression of AhR target genes [46], indicating that neonatal stage-specific upregulation of $\mathrm{PGE}_{2}$ synthesis is responsible for TiNH mediated by polyuria.

Remarkable differences in susceptibility among animal species and genetic backgrounds represent another challenge of TCDD toxicity evaluation. The lethal dose 50 (LD50) of TCDD for guinea pigs is 0.6 $\mu \mathrm{g} / \mathrm{kg}[12,63]$, whereas that for hamsters is $1160-5050 \mu \mathrm{g} / \mathrm{kg}[64,65]$. Even within species, sensitivity in response to TCDD can be considerably different: LD50 value for DBA $/ 2$ mice is $536 \mu \mathrm{g} / \mathrm{kg}$ and that for C57BL/ 6 mice is $114 \mu \mathrm{g} / \mathrm{kg}$ [66-68]. The susceptibility of humans to TCDD is predicted to be less than that of mice; this can be stated based on the case of Victor Yushchenko, who was intoxicated by TCDD with an estimated dose of about $25 \mu \mathrm{g} / \mathrm{kg}$ [69], and an experiment that utilized mice carrying humanized AhR [70]. Affinity of AhR to TCDD represents a determination factor for the sensitivity differences [67,71]. Little is known about additional factors determining sensitivity to TCDD toxicity. C57BL/6J and BALB/cA mice exhibit a substantial difference in the sensitivity to TiNH, although both strains possess AhRs with high affinity to TCDD [62]. This difference is attributed to the lower responsiveness of mPGES-1 expression to TCDD exposure in the kidney of BALB/cA pups. This finding proves the notion that factors responsible for a toxicity phenotype determine the susceptibility to toxicants [62].

\subsection{Pathophysiology and Mechanisms of TCDD-Induced Fetal Hydronephrosis}

A distinct characteristic of TCDD-induced fetal hydronephrosis (TiFH) is the presence of dilated ureters or hydroureter [43,72-74], which is not the case for TiNH at all [6,43,46]. In addition, Abbott et al. [72] found hyperplasia of ureter epithelium and occlusion of ureteric lumens in TCDD-exposed fetuses. The ureteric occlusion was further confirmed by ink injection from the bladder. Therefore, TiFH is an obstructive hydronephrosis with the following etiology. Ureter lumens are anatomically obstructed by TCDD-induced hyperplasia and the urine backpressure expands the ureter and pyelocaliceal space of the kidney, leading to renal parenchyma destruction.

In search for endogenous factors responsible for TiFH, AhR was identified as a molecule that is essential for TiFH development [5,75]. Although the mRNA level of CYP1A1 in the kidney of TCDD-exposed fetus is about 1,000 times higher than that in vehicle-control mice, CYP1A1 is not involved in TiFH onset because lack of CYP1 genes does not suppress TiFH onset [76]. As TCDD 
induces epithelial hyperplasia in the ureter in TiFH, growth factors have been investigated. TCDD increased the antibody immunoreactivity against EGFR [77] and increased the expression of EGFR ligands amphiregulin and epiregulin in fetus ureters [78]. However, in vivo experiments using mice lacking EGFR [79] and mice lacking epidermal growth factor (EGF) and/or fibroblast growth factor- $\alpha$ $\left(\right.$ FGF- $\alpha$ ) [80] do not support the hypothesis of EGFR being required for TiFH. Additionally, CPLA $A_{2} \alpha$ does not play a causative role in TiFH because genetic ablation of $\mathrm{CPLA}_{2} \alpha$ has little influence on TiFH onset [74]. Furthermore, the expression level of mPGES-1 mRNA is not affected by absence of cPLA $2 \alpha$ and/or by TCDD-exposure in the fetal kidney [74]. Thus, endogenous molecules, other than AhR, responsible for TiFH onset remain to be identified.

\subsection{Hydronephrosis in Rats}

TiFH and TiNH are also induced in rats [13,44]. Nishimura et al. [44] found that TCDD concentrations in the pups lactationally exposed to TCDD were similar in the cortex, outer zone of the medulla, and inner zone of the medulla of the kidney, whereas antibody immunoreactivity against CYP1A1, a typical AhR-dependent gene, was predominantly detected in the outer zone of the medulla. Based on the significant role of AhR in determining susceptibility to TCDD toxicities, activation of AhR in the outer zone of medulla may be responsible for the onset of hydronephrosis. It should be noted that $\mathrm{AhR}$ is required for the urinary tract development in a species-specific manner because the absence of $\mathrm{AhR}$ in rats causes hydroureter and hydronephrosis even in the absence of an exogenous ligand [81]. Such abnormalities in the urinary tract are observed in rats lacking AhR at 1 , 6 , and 12 weeks of age with $100 \%$ incidence. The etiological factors may be endogenous ligand(s) of $\mathrm{AhR}$ and/or protein(s) interacting with AhR. In contrast to rats, mice lacking AhR do not develop hydroureter or hydronephrosis in the absence of TCDD [5,6], suggesting that AhR has diverse roles in tissue development across species.

\section{Abnormal Development of Prostate}

In the process of prostate organogenesis, numerous prostate buds (prostate duct progenitors) develop from fetal urogenital sinus epithelium (UGE). The prostate buds initiate outgrowth into the surrounding urogenital sinus mesenchyme (UGM) and branching morphogenesis. In rodents, the prostate develops to form ventral, dorsolateral (dorsal and lateral), and anterior lobes (here, only referred to as ventral prostate and so on; see review [82] for detailed mechanisms of prostate organogenesis in human and mouse).

\subsection{Characteristics of TCDD-Induced Abnormality of Prostate Development}

In utero and lactational TCDD exposure of C57BL/6 J mice at a maternal dose of $5 \mu \mathrm{g} / \mathrm{kg}$ on GD 13 results in a barely detectable ventral prostate in the male offspring on PNDs 35, 90, 100, and $510[83,84]$, smaller weights of dorsolateral and anterior prostate on PND 35, fewer numbers of main ducts and ductal tips in lateral and dorsal prostate on PND 90, and consistently smaller overall structure of dorsolateral and anterior prostate on PND 90 [83]. A lower dose $(1 \mu \mathrm{g} / \mathrm{kg})$ of TCDD results in a decreased weight only in ventral prostate in adulthood, which might be associated with a decreased voiding pressure in the bladder [85]. A four-way cross fostering experiment indicated that ventral and anterior prostates are more sensitive to TCDD actions in the fetal period than in the neonatal period, whereas dorsolateral prostate is equally sensitive in these periods [86]. A more detailed study [87] revealed that TCDD exposure starting on GD 15.5 causes ventral prostate agenesis and that on GD 16.5 decreases ventral prostate weight by $50 \%$. Dorsolateral bud formation is most responsive to TCDD between GDs 14.5 and 15.5, and exposure during the sensitive period causes displaced buds and decreased bud number. Taken together, the critical window for TCDD toxicity varies between prostate lobes during prostate development in mice. 


\subsection{Molecular Basis of TCDD-Induced Prostate Malformations}

The following findings revealed that TCDD directly activates AhR in UGM to modulate paracrine signals, which inhibits prostatic bud formation in UGE. First, AhR-null mice are resistant to TCDD-induced abnormalities of prostate development (decrease in weight of prostatic lobes and altered expression levels of differentiation marker genes) [88]. Second, mRNAs of AhR and indicator genes of AhR activation exhibit histologically overlapping distributions in the periprostatic mesenchyme, which closely contacts UGE in the TCDD-exposed fetus [87]. Third, TCDD prevents prostatic epithelial buds from forming in cultured urogenital sinus derived from wild-type mice but not from AhR-null mice [89]. Fourth, TCDD-exposed organ cultures of dorsolateral or ventral UGM in combination with UGE result in loss of budding from the epithelium when the ventral mesenchyme is from wild type mice but not from AhR-null mice [90]. The loss of budding is observed regardless of the genotype of the epithelium, indicating that AhR expression not in the epithelium but in UGM has a role in the budding [90]. It should be noted that AhR has a role in prostate development, because loss of functional AhR causes delays in growth of prostatic lobes and seminal vesicle in the absence of an exogenous ligand [88]. Therefore, it is thought that TCDD acts on AhR to induce responses in the developing prostate in a complicated manner.

The Wnt/ $\beta$-catenin signaling cascade may link AhR activation and ventral prostate agenesis. TCDD alters expression levels of genes regulating Wnt signaling around the timing and location of the budding [91]. In addition, treatment with an anti-Wnt5a antibody restores a TCDD-induced decrease in prostatic buds in an organ culture system [92]. These results suggest a possible mechanism involving Wnt signaling. $\beta$-catenin activation is indicated in the ventral basal epithelium immediately prior to the initiation of ventral prostatic budding, which is abolished by TCDD exposure [91]. Based on these findings, it is proposed that AhR activation alters Wnt ligands expression in UGM, which disrupts regulation of $\beta$-catenin signaling via the receptors for Wnt ligands in UGE and subsequently inhibits the budding [93].

\section{Heart and Craniofacial Malformations}

Fish species are extremely susceptible to TCDD exposure and exhibit similar toxicity phenotypes to those observed in other vertebrates, including wasting syndrome, delayed mortality, cardiovascular dysfunction, craniofacial malformations, and liver damage (see the review by King-Heiden et al. [94]). AHR2 in fish is the functional orthologue of mammalian AhR [95]. This section will focus on the heart and craniofacial malformations that have been extensively investigated in zebrafish (Danio rerio) embryos. TCDD exposure levels in this section are expressed as TCDD concentrations in water based on the studies cited in this review although the actual TCDD concentrations in water are uncertain owing to TCDD's very high log Kow [96], while describing the exposure level as tissue TCDD concentration may be more applicable to risk assessment in the real world [97].

\subsection{Heart Malformation}

When fertilized zebrafish eggs are exposed for $1 \mathrm{~h}$ to waterborne TCDD ( $1 \mathrm{ppb}$, or $1 \mathrm{ng} / \mathrm{g}$, nearly equivalent to $1 \mathrm{ng} / \mathrm{mL}$ ) [98] shortly after fertilization, severe heart malformation is observed in the embryos. Exposure at 7, 12, and 30 days post-fertilization results in less severe, far more modest, and no detectable defects, respectively [98]. Major characteristics of the heart malformation at $72 \mathrm{~h}$ and $96 \mathrm{~h}$ post-fertilization (hpf) in the embryo exposed to $1 \mathrm{ppb}$ TCDD for $1 \mathrm{~h}$ involve a failure to form the looping shape of the heart, elongated atrium, and shrunken ventricle [99]. TCDD exposure reduces the number of cardiac myocytes based on the marker gene cmlc2 expression at $48 \mathrm{hpf}$, which precedes observable effects on peripheral blood flow by one day [99]. The cells primarily affected by TCDD are those of the proepicardium [100]. TCDD exposure at $24 \mathrm{hpf}$ (before the proepicardium formation) almost diminishes proepicardium on the ventricle or atrium at $50 \mathrm{hpf}$ or $72 \mathrm{hpf}$, whereas proepicardium is formed in control embryos at these times. Delaying the start of TCDD exposure 
from the $24 \mathrm{hpf}$ to $48 \mathrm{hpf}, 72 \mathrm{hpf}, 96 \mathrm{hpf}$, and $122 \mathrm{hpf}$ reduces this effect. The proepicardium cells on the myocardium, formed in the developing heart, subsequently form the epicardium. This process is lost when exposed to TCDD during proepicardium formation but not after epicardium formation, accounting for the windows of sensitivity to the severest form of heart malformation [98]. Thus, TCDD interferes with a distinct type of progenitor cells during development, which propagates to cause heart malformation. The major characteristics of heart malformation and loss of epicardium are not secondary to pericardial edema because suppression of the edema by osmotic support with mannitol does not alleviate these abnormalities $[99,100]$. TCDD exposure at a much lower dose $(1 \mathrm{ng} / \mathrm{L})$ for 4 days induces a reduction in ventricular length at 10 days post-fertilization [101], indicating that heart morphogenesis is extremely sensitive to TCDD exposure.

A genetically modified zebrafish embryo, carrying a constitutively activated AhR (caAHR) under the control of the cardiomyocyte-specific gene cmlc2 promoter [102], fails to form epicardium and develops heart malformation characterized by an unlooped heart with an elongated atrium and a shrunken ventricle. Additionally, heart functions in the caAHR-zebrafish are inhibited similarly to those of TCDD-exposed wild-type zebrafish. A significant role of AHR2 in TCDD-induced heart malformation has been demonstrated using an antisense morpholino [95]. Recently, Souder and Gorelick [103] reported that a newly generated AHR2 mutant is resistant to $10 \mathrm{ng} / \mathrm{mL}$ TCDD exposure and does not produce abnormal heart looping or severe pericardial edema in contrast to the corresponding wild-type embryos and mutants of AHR1A and AHR1B. It is not clear whether the lack of functional AHR2 in other AHR2 mutant lines described above $[7,104]$ also blocks heart malformation. The gene Sry-box containing $9 b$ (sox9b) links AhR activation with heart malformation [105]; sox $9 b$ expression in the heart ventricle at $72 \mathrm{hpf}$ is significantly reduced by TCDD exposure, and the sox $9 b$-null mutant zebrafish shows heart malformation, such as failure to form the looping shape of the heart, elongated atrium, and shrunk ventricle. In addition, loss of sox $9 \mathrm{~b}$ prevents formation of proepicardium and epicardium [105]. Cardiomyocyte-specific Sox9b inhibition by a dominant-negative mutant protein [106] results in abnormalities similar to those of TCDD-induced heart malformation, indicating the pivotal role of sox $9 \mathrm{~b}$ in epicardium formation and subsequent heart development.

\subsection{Craniofacial Malformation}

When fertilized zebrafish eggs are exposed to waterborne TCDD $(0.3-7.4 \mathrm{ng} / \mathrm{g}$ water), craniofacial malformations, such as foreshortened snout and underdeveloped lower jaw, are observed at 60-240 hpf [107-109]. The effective dose 50 (ED50) for craniofacial malformations of embryos exposed to TCDD from $24 \mathrm{hpf}$ to $48 \mathrm{hpf}$ is $1.9 \mathrm{ng}$ TCDD/g embryo at $240 \mathrm{hpf}$ [108]. No specific window for the underdevelopment of the lower jaw was identified within 0-96 hpf [107-109]. Detailed analyses of the jaw morphology revealed that cartilage had abnormal structures with a smaller size in the TCDD-exposed embryos $[7,31,107,109]$. Chondrocytes are the affected cell type in the cartilage, as their number and length are decreased by TCDD exposure [31]. In addition, endodermal perichondrial cells that cover chondrocytes are affected by TCDD due to which they develop a reduced proliferation ability [31]. Furthermore, TCDD reduces ossification of craniofacial osteoblasts [31], which is consistent with TCDD-induced ossification failure in another fish model, medaka (Oryzias latipes) [110]. These findings indicate that chondrocytes and the peripheral cells are sensitive to TCDD insult, leading to malformations. It should be noted that dimethyl sulfoxide (DMSO), a solvent used to dilute TCDD, has recently been shown to alter cartilage structures; Meckel's and platoquadrate cartilages in DMSO-exposed zebrafish manifest slightly but statistically significant differences in their relative position compared to those in non-exposed zebrafish [7]. Possible interactions of TCDD and DMSO may complicate the interpretations of the experimental results.

It has been suggested that reduced blood flow plays a role in TCDD-induced jaw malformation. This suggestion is reasonable because cardiomyocyte-specific activation of AhR induces jaw underdevelopment in addition to the expected cardiac defects [102]. A zebrafish model of 
cardiac dysfunction develops abnormal jaw growth in the absence of TCDD [111]. On the other hand, the abnormality of the lower jaw develops before the cardiovascular abnormalities are not evident $[107,109]$. Taken together, the direct action of TCDD on the lower jaw and the indirect action via the circulation failure could contribute to TCDD-induced jaw malformation.

AHR2 mediates TCDD-induced craniofacial malformations in zebrafish as AHR2-null zebrafish are resistant to the toxicity [7]. Additionally, the zebrafish mutant line AHR2 ${ }^{\text {hu3335, with a }}$ mutation in the transactivation domain [104], and zebrafish embryos injected with an antisense morpholino targeting AHR2 [112] are completely and partially resistant to development of craniofacial malformations, respectively. These studies clearly established that AHR2 is responsible for the TCDD-induced craniofacial malformation. Interestingly, AHR2-null zebrafish have cranial skeletal bone structure abnormality in adulthood even when TCDD is not administered, demonstrating endogenous functions of AHR2 in the development of skeletal bones. SOX9b is a critical chondrogenic transcription factor; deletion of sox $9 \mathrm{~b}$ results in jaw abnormalities of a considerably more severe degree compared with those induced by TCDD exposure [113]. AHR2-dependent reduction in SOX9b expression is thought to contribute to jaw malformation because of the following reasons. An antisense morpholino against sox $9 b$ mimics TCDD-induced jaw malformation and restoration of sox $9 b$ expression rescues the developing jaw from TCDD exposure [109]. TCDD induced-jaw malformation accompanies significant reduction in sox $9 b$ expression only in wild-type control allele but not in AHR2-null allele [7]. A reporter gene for sox $9 b$ promoter activity shows expression in perichondrial cells surrounding craniofacial cartilages [31]. In addition, TCDD-induced reduction in both sox $9 b$ expression and abnormality in jaw structure are also observed in medaka (Oryzias latipes) [110], suggesting a common role of sox $9 b$ among fish species. The extent to which reduction in sox $9 b$ expression affects TCDD-induced craniofacial malformations remains to be uncovered; the craniofacial malformations are observed at a TCDD dose $(0.25 \mathrm{ng} / \mathrm{mL})$ at which a reduction in sox $9 b$ mRNA level in the whole embryo is not evident [114]. The noncoding RNA slincR may link transactivation capacity of AHR2 with reduction in sox $9 b$ expression; the slincR promoter has cis-elements for AHR2-binding and TCDD upregulates slincR expression in an AHR2-dependent manner [7,115]. In addition, slincR transcripts are suggested to be enriched in a region of the genome corresponding to the $5^{\prime}$-untranslated region (UTR) of sox $9 b$ [114] and an antisense-morpholino-mediated suppression of slincR expression cancels the reduction of sox $9 b$ expression in the presence of TCDD [115]. The knock-down of slincR using an antisense morpholino altered the structures of jaw cartilages in TCDD-exposed zebrafish [114]. The exact roles and contribution of the slincR/sox $9 b$ pathway should be examined further since slincR and sox $9 b$ only partially overlap with respect to expression time and location [115].

\section{Perspectives for Future Research}

Toxicological research on dioxin and related compounds was initiated for risk assessment after episodic accidents of humans exposed to these chemicals in the general and occupational environments. These episodes include accidents in Seveso, Italy [116,117], food poisoning accidents named Yusho and Yucheng in Japan and Taiwan, respectively [118], and Victor Yuchenko's incidence [69], which suggest that daily exposure to these chemicals even at low doses may induce abnormalities, in particular, when exposed during the most sensitive period of development. In the risk assessment of dioxin and related compounds, developmental toxicity data obtained from animals exposed in utero and via lactation have been utilized [119]. In this risk assessment, the concept of body burden that reflects actual dioxin concentration in the blood circulation was practically used to minimize the effects of route of administration between humans and experimental animals. However, there exists a non-negligible limitation in the extrapolation of TCDD toxicity data from animals to humans. In TCDD toxicity studies, the animal species and strains that are sensitive to respond to TCDD have been often used on the standpoint to protect human health. The tolerable daily intake (TDI) value and tolerable monthly intake value are $4 \mathrm{pg}$ toxic equivalency (TEQ)/ $\mathrm{kg}$ per day [119] and $70 \mathrm{pg}$ TEQ/kg per month [120], respectively. Because AhR structure significantly determines a difference 
in susceptibility between animal species and between strains, the selection of a particular kind of species or strains would affect the TDI value. Although there is no ideal species or strains that is multipotent for risk assessment, production of humanized AhR knock-in mice would be an option as an experimental model. In a humanized AhR mouse model [70], in which C57BL/6 AhR is replaced with human AhR, the TCDD-exposed animals turned out to be less susceptible than C57BL/ 6 and DBA $/ 2$ in terms of the onset of cleft palate and hydronephrosis. It should be noted that once human $\mathrm{AhR}$ is introduced into the murine cells, cofactors that supposedly interact with AhR are of murine origin, which suggest that these cells behave differently from those of human origins. As described in the above section, the AhR response to TCDD seems to totally differ between mice and rats because AhR-null rats manifest hydronephrosis without TCDD. The molecular mechanisms of AhR and cofactors with AhR ligands need further studies. The other limitation is the difficulty of determining an exact critical period during the developmental period. When dams are exposed during gestation, TCDD will be transferred to fetuses and neonates via placenta and via lactation, respectively. Although cross-fostering experiments have been performed to determine the critical period, it is often difficult to estimate the TCDD concentration at a target site of an organ during development. The fact that organogenesis during ontogeny does not necessarily match between rodents and humans is another factor that complicates interpreting toxicity data of animal models during gestation.

\section{Conclusions}

Dioxin and related compounds induce various toxicities in an AhR-dependent manner. Identification of AhR as a dioxin receptor and the use of AhR-null animals and cells have clearly showed that AhR is essential to induce majority of the toxicities and achieved a breakthrough in the field of dioxin toxicology. The physiologic role of AhR remains unclear. On the other hand, it avidly binds TCDD to mediate signals downstream of AhR to induce abnormalities. The mechanisms of these abnormalities have been intensively unveiled for cleft palate, hydronephrosis, abnormal development of prostate, and heart and craniofacial malformation. In some cases, AhR is likely to function in the absence of dioxin-like chemicals. Elucidating the mechanisms of endogenous and naturally occurring AhR ligands and clarification of the AhR signaling network consisting of cross talks of endogenous and exogenous ligands will be the next challenges.

Recent studies have progressed in elucidating the molecular basis of specific toxicity phenotypes by combining genetic strategies targeting genes potentially involved in the mechanisms and detailed investigations of the pathophysiology of the toxicity phenotypes and/or cell types affected. Entire pathways from TCDD-exposure to the onset of toxicity phenotypes are to be unraveled in the near future. Humans and wild life have been exposed to dioxins and related compounds at a very low concentration. Although extrapolation of data from animal models to humans requires scrutiny in future studies, the use of TCDD as a prototype of these chemicals will be helpful for studying the molecular mechanism of toxicities that might be common in animals and humans.

Funding: This research was funded by JSPS KAKENHI Grant Number 16H05889 (to WY).

Conflicts of Interest: The authors declare no conflict of interest.

\section{Abbreviations}

AhR Aryl hydrocarbon receptor

GD Gestational day

PND Postnatal day

hpf Hour(s) post-fertilization 


\section{References}

1. Van den Berg, M.; Birnbaum, L.S.; Denison, M.; De Vito, M.; Farland, W.; Feeley, M.; Fiedler, H.; Hakansson, H.; Hanberg, A.; Haws, L.; et al. The 2005 world health organization reevaluation of human and mammalian toxic equivalency factors for dioxins and dioxin-like compounds. Toxicol. Sci. 2006, 93, $223-241$. [CrossRef] [PubMed]

2. Couture, L.A.; Abbott, B.D.; Birnbaum, L.S. A critical review of the developmental toxicity and teratogenicity of 2,3,7,8-tetrachlorodibenzo- $p$-dioxin: Recent advances toward understanding the mechanism. Teratology 1990, 42, 619-627. [CrossRef] [PubMed]

3. Nebert, D.W. Aryl hydrocarbon receptor (AHR): "Pioneer member" of the basic-helix/loop/helix per-Arnt-sim (bHLH/PAS) family of "sensors" of foreign and endogenous signals. Prog. Lipid Res. 2017, 67, 38-57. [CrossRef] [PubMed]

4. Hahn, M.E.; Karchner, S.I.; Merson, R.R. Diversity as opportunity: Insights from 600 million years of AHR evolution. Curr. Opin. Toxicol. 2017, 2, 58-71. [CrossRef] [PubMed]

5. Mimura, J.; Yamashita, K.; Nakamura, K.; Morita, M.; Takagi, T.N.; Nakao, K.; Ema, M.; Sogawa, K.; Yasuda, M.; Katsuki, M.; et al. Loss of teratogenic response to 2,3,7,8-tetrachlorodibenzo-p-dioxin (TCDD) in mice lacking the Ah (dioxin) receptor. Genes Cells 1997, 2, 645-654. [CrossRef] [PubMed]

6. Nishimura, N.; Matsumura, F.; Vogel, C.F.; Nishimura, H.; Yonemoto, J.; Yoshioka, W.; Tohyama, C. Critical role of cyclooxygenase-2 activation in pathogenesis of hydronephrosis caused by lactational exposure of mice to dioxin. Toxicol. Appl. Pharmacol. 2008, 231, 374-383. [CrossRef] [PubMed]

7. Garcia, G.R.; Bugel, S.M.; Truong, L.; Spagnoli, S.; Tanguay, R.L. AHR2 required for normal behavioral responses and proper development of the skeletal and reproductive systems in zebrafish. PLoS ONE 2018, 13, e0193484. [CrossRef] [PubMed]

8. Yoshioka, W.; Peterson, R.E.; Tohyama, C. Molecular targets that link dioxin exposure to toxicity phenotypes. J. Steroid Biochem. Mol. Biol. 2011, 127, 96-101. [CrossRef] [PubMed]

9. Parker, S.E.; Mai, C.T.; Canfield, M.A.; Rickard, R.; Wang, Y.; Meyer, R.E.; Anderson, P.; Mason, C.A.; Collins, J.S.; Kirby, R.S.; et al. Updated national birth prevalence estimates for selected birth defects in the united states, 2004-2006. Birth Defects Res. Part A 2010, 88, 1008-1016. [CrossRef] [PubMed]

10. Natsume, N.; Niimi, T.; Furukawa, H.; Kawai, T.; Ogi, N.; Suzuki, Y.; Kawai, T. Survey of congenital anomalies associated with cleft lip and/or palate in 701,181 Japanese people. Oral Surg. Oral Med. Oral Pathol. Oral Radiol. Endod. 2001, 91, 157-161. [CrossRef]

11. Kransler, K.M.; McGarrigle, B.P.; Olson, J.R. Comparative developmental toxicity of 2,3,7,8-tetrachlorodibenzo$p$-dioxin in the hamster, rat and guinea pig. Toxicology 2007, 229, 214-225. [CrossRef]

12. Schwetz, B.A.; Norris, J.M.; Sparschu, G.L.; Rowe, U.K.; Gehring, P.J.; Emerson, J.L.; Gerbig, C.G. Toxicology of chlorinated dibenzo-p-dioxins. Environ. Health Perspect. 1973, 5, 87-99. [CrossRef] [PubMed]

13. Courtney, K.D.; Moore, J.A. Teratology studies with 2,4,5-trichlorophenoxyacetic acid and 2,3,7,8-tetrachlorodibenzo-p-dioxin. Toxicol. Appl. Pharmacol. 1971, 20, 396-403. [CrossRef]

14. Yamada, T.; Mishima, K.; Fujiwara, K.; Imura, H.; Sugahara, T. Cleft lip and palate in mice treated with 2,3,7,8-tetrachlorodibenzo-p-dioxin: A morphological in vivo study. Congenit. Anom. 2006, 46, 21-25. [CrossRef] [PubMed]

15. Pratt, R.M.; Dencker, L.; Diewert, V.M. 2,3,7,8-tetrachlorodibenzo-p-dioxin-induced cleft palate in the mouse: Evidence for alterations in palatal shelf fusion. Teratog. Carcinog. Mutagen. 1984, 4, 427-436. [CrossRef] [PubMed]

16. Couture, L.A.; Harris, M.W.; Birnbaum, L.S. Characterization of the peak period of sensitivity for the induction of hydronephrosis in C57BL6N mice following exposure to 2,3,7,8-tetrachlorodibenzo- $p$-dioxin. Fundam. Appl. Toxicol. 1990, 15, 142-150. [CrossRef]

17. Yoon, B.I.; Inoue, T.; Kaneko, T. Teratological effect of 2,3,7,8-tetrachlorodibenzo- $p$-dioxin (TCDD): Induction of cleft palate in the ddy and C57BL/6 mouse. J. Vet. Sci. 2000,1, 113-119.

18. Buser, M.C.; Pohl, H.R. Windows of sensitivity to toxic chemicals in the development of cleft palates. J. Toxicol. Environ. Health Part B 2015, 18, 242-257. [CrossRef]

19. Pratt, R.M. Mechanisms of chemically-induced cleft palate. Trends Pharmacol. Sci. 1983, 4, 160-162. [CrossRef]

20. Lan, Y.; Xu, J.; Jiang, R. Cellular and molecular mechanisms of palatogenesis. Curr. Top. Dev. Biol. 2015, 115, 59-84. 
21. Fujiwara, K.; Yamada, T.; Mishima, K.; Imura, H.; Sugahara, T. Morphological and immunohistochemical studies on cleft palates induced by 2,3,7,8-tetrachlorodibenzo- $p$-dioxin in mice. Congenit. Anom. 2008, 48, 68-73. [CrossRef] [PubMed]

22. Imura, H.; Yamada, T.; Mishima, K.; Fujiwara, K.; Kawaki, H.; Hirata, A.; Sogawa, N.; Ueno, T.; Sugahara, T. Effect of 2,3,7,8-tetrachlorodibenzo- $p$-dioxin suggests abnormal palate development after palatal fusion. Congenit. Anom. 2010, 50, 77-84. [CrossRef]

23. Yamada, T.; Hirata, A.; Sasabe, E.; Yoshimura, T.; Ohno, S.; Kitamura, N.; Yamamoto, T. TCDD disrupts posterior palatogenesis and causes cleft palate. J. Cranio-Maxillofac. Surg. 2014, 42, 1-6. [CrossRef] [PubMed]

24. Takagi, T.N.; Matsui, K.A.; Yamashita, K.; Ohmori, H.; Yasuda, M. Pathogenesis of cleft palate in mouse embryos exposed to 2,3,7, 8-tetrachlorodibenzo-p-dioxin (TCDD). Teratog. Carcinog. Mutagen. 2000, 20, 73-86. [CrossRef]

25. Sakuma, C.; Imura, H.; Yamada, T.; Sugahara, T.; Hirata, A.; Ikeda, Y.; Natsume, N. Cleft palate formation after palatal fusion occurs due to the rupture of epithelial basement membranes. J. Craniomaxillofac. Surg. 2018. [CrossRef] [PubMed]

26. Thomae, T.L.; Stevens, E.A.; Bradfield, C.A. Transforming growth factor- $\beta 3$ restores fusion in palatal shelves exposed to 2,3,7,8-tetrachlorodibenzo-p-dioxin. J. Biol. Chem. 2005, 280, 12742-12746. [CrossRef] [PubMed]

27. Abbott, B.D.; Birnbaum, L.S. TCDD alters medial epithelial cell differentiation during palatogenesis. Toxicol. Appl. Pharmacol. 1989, 99, 276-286. [CrossRef]

28. Abbott, B.D.; Diliberto, J.J.; Birnbaum, L.S. 2,3,7,8-tetrachlorodibenzo-p-dioxin alters embryonic palatal medial epithelial cell differentiation in vitro. Toxicol. Appl. Pharmacol. 1989, 100, 119-131. [CrossRef]

29. Yuan, X.; Qiu, L.; Pu, Y.; Liu, C.; Zhang, X.; Wang, C.; Pu, W.; Fu, Y. Histone acetylation is involved in TCDDinduced cleft palate formation in fetal mice. Mol. Med. Rep. 2016, 14, 1139-1145. [CrossRef]

30. Gan, L.Q.; Fu, Y.X.; Liu, X.; Qiu, L.; Wu, S.D.; Tian, X.F.; Liu, Y.; Wei, G.H. Transforming growth factor- $\beta 3$ expression up-regulates on cleft palates induced by 2,3,7,8-tetrachlorodibenzo-p-dioxin in mice. Toxicol. Ind. Health 2009, 25, 473-478. [CrossRef]

31. Burns, F.R.; Peterson, R.E.; Heideman, W. Dioxin disrupts cranial cartilage and dermal bone development in zebrafish larvae. Aquat. Toxicol. 2015, 164, 52-60. [CrossRef] [PubMed]

32. Frøkiær, J.; Zeidel, M.L. Urinary tract obstruction. In The kidney, 9th ed.; Taal, M.W., Chertow, G.M., Marsden, P.A., Skorecki, K., Yu, A.S.L., Brenner, B.M., Eds.; Elsevier Saunders: Philadelphia, PA, USA, 2011; Volume 1, pp. 1383-1410.

33. Lee, R.S.; Cendron, M.; Kinnamon, D.D.; Nguyen, H.T. Antenatal hydronephrosis as a predictor of postnatal outcome: A meta-analysis. Pediatrics 2006, 118, 586-593. [CrossRef]

34. Yamacake, K.G.; Nguyen, H.T. Current management of antenatal hydronephrosis. Pediatr. Nephrol. 2013, $28,237-243$. [CrossRef] [PubMed]

35. Smith, C.L.; Blake, J.A.; Kadin, J.A.; Richardson, J.E.; Bult, C.J.; Mouse Genome Database Group. Mouse genome database (MGD)-2018: Knowledgebase for the laboratory mouse. Nucleic Acids Res. 2018, 46, D836-D842. [CrossRef]

36. MGD. Search Results for "Hydronephrosis". Available online: http://www.informatics.jax.org/searchtool/ Search.do?query=hydronephrosis (accessed on 12 December 2018).

37. Nomura, N.; Tajima, M.; Sugawara, N.; Morimoto, T.; Kondo, Y.; Ohno, M.; Uchida, K.; Mutig, K.; Bachmann, S.; Soleimani, M.; et al. Generation and analyses of R8L barttin knockin mouse. Am. J. Physiol. Renal Physiol. 2011, 301, F297-F307. [CrossRef] [PubMed]

38. Shi, P.P.; Cao, X.R.; Qu, J.; Volk, K.A.; Kirby, P.; Williamson, R.A.; Stokes, J.B.; Yang, B. Nephrogenic diabetes insipidus in mice caused by deleting cooh-terminal tail of aquaporin-2. Am. J. Physiol. Renal Physiol. 2007, 292, F1334-F1344. [CrossRef] [PubMed]

39. Takahashi, N.; Chernavvsky, D.R.; Gomez, R.A.; Igarashi, P.; Gitelman, H.J.; Smithies, O. Uncompensated polyuria in a mouse model of bartter's syndrome. Proc. Natl. Acad. Sci. USA 2000, 97, 5434-5439. [CrossRef] [PubMed]

40. Kemter, E.; Rathkolb, B.; Bankir, L.; Schrewe, A.; Hans, W.; Landbrecht, C.; Klaften, M.; Ivandic, B.; Fuchs, H.; Gailus-Durner, V.; et al. Mutation of the $\mathrm{Na}^{+}-\mathrm{K}^{+}-2 \mathrm{Cl}^{-}$cotransporter NKCC2 in mice is associated with severe polyuria and a urea-selective concentrating defect without hyperreninemia. Am. J. Physiol. Renal. Physiol. 2010, 298, F1405-F1415. [CrossRef] 
41. Jeong, H.W.; Jeon, U.S.; Koo, B.K.; Kim, W.Y.; Im, S.K.; Shin, J.; Cho, Y.; Kim, J.; Kong, Y.Y. Inactivation of notch signaling in the renal collecting duct causes nephrogenic diabetes insipidus in mice. J. Clin. Investig. 2009, 119, 3290-3300. [CrossRef]

42. Yun, J.; Schoneberg, T.; Liu, J.; Schulz, A.; Ecelbarger, C.A.; Promeneur, D.; Nielsen, S.; Sheng, H.; Grinberg, A.; Deng, C.; et al. Generation and phenotype of mice harboring a nonsense mutation in the V2 vasopressin receptor gene. J. Clin. Investig. 2000, 106, 1361-1371. [CrossRef]

43. Moore, J.A.; Gupta, B.N.; Zinkl, J.G.; Vos, J.G. Postnatal effects of maternal exposure to 2,3,7,8-tetrachlorodibenzo-p-dioxin (TCDD). Environ. Health Perspect. 1973, 5, 81-85. [CrossRef] [PubMed]

44. Nishimura, N.; Yonemoto, J.; Nishimura, H.; Tohyama, C. Localization of cytochrome P450 1A1 in a specific region of hydronephrotic kidney of rat neonates lactationally exposed to 2,3,7,8-tetrachlorodibenzo- $p$-dioxin. Toxicology 2006, 227, 117-126. [CrossRef] [PubMed]

45. Couture-Haws, L.; Harris, M.W.; McDonald, M.M.; Lockhart, A.C.; Birnbaum, L.S. Hydronephrosis in mice exposed to TCDD-contaminated breast milk: Identification of the peak period of sensitivity and assessment of potential recovery. Toxicol. Appl. Pharmacol. 1991, 107, 413-428. [CrossRef]

46. Yoshioka, W.; Kawaguchi, T.; Nishimura, N.; Akagi, T.; Fujisawa, N.; Yanagisawa, H.; Matsumura, F.; Tohyama, C. Polyuria-associated hydronephrosis induced by xenobiotic chemical exposure in mice. Am. J. Physiol. Renal Physiol. 2016, 311, F752-F762. [CrossRef] [PubMed]

47. Yoshioka, W.; Aida-Yasuoka, K.; Fujisawa, N.; Kawaguchi, T.; Ohsako, S.; Hara, S.; Uematsu, S.; Akira, S.; Tohyama, C. Critical role of microsomal prostaglandin E synthase-1 in the hydronephrosis caused by lactational exposure to dioxin in mice. Toxicol. Sci. 2012, 127, 547-554. [CrossRef] [PubMed]

48. Yoshioka, W.; Kawaguchi, T.; Fujisawa, N.; Aida-Yasuoka, K.; Shimizu, T.; Matsumura, F.; Tohyama, C. Predominant role of cytosolic phospholipase $\mathrm{A}_{2} \alpha$ in dioxin-induced neonatal hydronephrosis in mice. Sci. Rep. 2014, 4, 4042. [CrossRef] [PubMed]

49. Dong, B.; Matsumura, F. Roles of cytosolic phospholipase A2 and Src Kinase in the early action of 2,3,7,8-tetrachlorodibenzo- $p$-dioxin through a nongenomic pathway in MCF10A cells. Mol. Pharmacol. 2008, 74, 255-263. [CrossRef]

50. Dong, B.; Nishimura, N.; Vogel, C.F.; Tohyama, C.; Matsumura, F. TCDD-induced cyclooxygenase-2 expression is mediated by the nongenomic pathway in mouse MMDD1 macula densa cells and kidneys. Biochem. Pharmacol. 2010, 79, 487-497. [CrossRef]

51. Kinehara, M.; Fukuda, I.; Yoshida, K.; Ashida, H. Aryl hydrocarbon receptor-mediated induction of the cytosolic phospholipase $\mathrm{A}_{2} \alpha$ gene by 2,3,7,8-tetrachlorodibenzo- $p$-dioxin in mouse hepatoma Hepa-1c1c7 cells. J. Biosci. Bioeng. 2009, 108, 277-281. [CrossRef]

52. Kinehara, M.; Fukuda, I.; Yoshida, K.; Ashida, H. High-throughput evaluation of aryl hydrocarbon receptor-binding sites selected via chromatin immunoprecipitation-based screening in Hepa-1c1c7 cells stimulated with 2,3,7,8-tetrachlorodibenzo-p-dioxin. Genes Genet Syst. 2008, 83, 455-468. [CrossRef]

53. Vorderstrasse, B.A.; Fenton, S.E.; Bohn, A.A.; Cundiff, J.A.; Lawrence, B.P. A novel effect of dioxin: Exposure during pregnancy severely impairs mammary gland differentiation. Toxicol. Sci. 2004, 78, 248-257. [CrossRef]

54. Basham, K.J.; Leonard, C.J.; Kieffer, C.; Shelton, D.N.; McDowell, M.E.; Bhonde, V.R.; Looper, R.E.; Welm, B.E. Dioxin exposure blocks lactation through a direct effect on mammary epithelial cells mediated by the aryl hydrocarbon receptor repressor. Toxicol. Sci. 2015, 143, 36-45. [CrossRef]

55. Lew, B.J.; Manickam, R.; Lawrence, B.P. Activation of the aryl hydrocarbon receptor during pregnancy in the mouse alters mammary development through direct effects on stromal and epithelial tissues. Biol. Reprod. 2011, 84, 1094-1102. [CrossRef]

56. Mimura, J.; Fujii-Kuriyama, Y. Functional role of AHR in the expression of toxic effects by TCDD. Biochim. Biophys. Acta 2003, 1619, 263-268. [CrossRef]

57. Murray, I.A.; Perdew, G.H. Omeprazole stimulates the induction of human insulin-like growth factor binding protein-1 through aryl hydrocarbon receptor activation. J. Pharmacol. Exp. Ther. 2008, 324, 1102-1110. [CrossRef]

58. Matsumura, F. The significance of the nongenomic pathway in mediating inflammatory signaling of the dioxin-activated Ah receptor to cause toxic effects. Biochem. Pharmacol. 2009, 77, 608-626. [CrossRef]

59. Zelenina, M.; Christensen, B.M.; Palmer, J.; Nairn, A.C.; Nielsen, S.; Aperia, A. Prostaglandin E $E_{2}$ interaction with AVP: Effects on AQP2 phosphorylation and distribution. Am. J. Physiol. Renal Physiol. 2000, 278, F388-F394. [CrossRef] 
60. Nadler, S.P.; Zimpelmann, J.A.; Hebert, R.L. PGE2 inhibits water permeability at a post-cAMP site in rat terminal inner medullary collecting duct. Am. J. Physiol. 1992, 262, F229-F235. [CrossRef]

61. Hebert, R.L.; Jacobson, H.R.; Fredin, D.; Breyer, M.D. Evidence that separate PGE2 receptors modulate water and sodium transport in rabbit cortical collecting duct. Am. J. Physiol. 1993, 265, F643-F650. [CrossRef]

62. Aida-Yasuoka, K.; Yoshioka, W.; Kawaguchi, T.; Ohsako, S.; Tohyama, C. A mouse strain less responsive to dioxin-induced prostaglandin E2 synthesis is resistant to the onset of neonatal hydronephrosis. Toxicol. Sci. 2014, 141, 465-474. [CrossRef]

63. McConnell, E.E.; Moore, J.A.; Haseman, J.K.; Harris, M.W. The comparative toxicity of chlorinated dibenzo-p-dioxins in mice and guinea pigs. Toxicol. Appl. Pharmacol. 1978, 44, 335-356. [CrossRef]

64. Henck, J.M.; New, M.A.; Kociba, R.J.; Rao, K.S. 2,3,7,8-tetrachlorodibenzo-p-dioxin: Acute oral toxicity in hamsters. Toxicol. Appl. Pharmacol. 1981, 59, 405-407. [CrossRef]

65. Olson, J.R.; Gasiewicz, T.A.; Neal, R.A. Tissue distribution, excretion, and metabolism of 2,3,7,8-tetrachlorodibenzo- $p$-dioxin (TCDD) in the golden syrian hamster. Toxicol. Appl. Pharmacol. 1980, 56, 78-85. [CrossRef]

66. Shen, E.S.; Gutman, S.I.; Olson, J.R. Comparison of 2,3,7,8-tetrachlorodibenzo-p-dioxin-mediated hepatotoxicity in C57BL/6J and DBA/2J mice. J. Toxicol. Environ. Health 1991, 32, 367-381. [CrossRef]

67. Poland, A.; Palen, D.; Glover, E. Analysis of the four alleles of the murine aryl hydrocarbon receptor. Mol. Pharmacol. 1994, 46, 915-921.

68. Ema, M.; Ohe, N.; Suzuki, M.; Mimura, J.; Sogawa, K.; Ikawa, S.; Fujii-Kuriyama, Y. Dioxin binding activities of polymorphic forms of mouse and human arylhydrocarbon receptors. J. Biol. Chem. 1994, 269, 27337-27343.

69. Sorg, O.; Zennegg, M.; Schmid, P.; Fedosyuk, R.; Valikhnovskyi, R.; Gaide, O.; Kniazevych, V.; Saurat, J.H. 2,3,7,8-tetrachlorodibenzo- $p$-dioxin (TCDD) poisoning in victor yushchenko: Identification and measurement of TCDD metabolites. Lancet 2009, 374, 1179-1185. [CrossRef]

70. Moriguchi, T.; Motohashi, H.; Hosoya, T.; Nakajima, O.; Takahashi, S.; Ohsako, S.; Aoki, Y.; Nishimura, N.; Tohyama, C.; Fujii-Kuriyama, Y.; et al. Distinct response to dioxin in an arylhydrocarbon receptor (AHR)-humanized mouse. Proc. Natl. Acad. Sci. USA 2003, 100, 5652-5657. [CrossRef]

71. Poland, A.; Glover, E. 2,3,7,8,-tetrachlorodibenzo- $p$-dioxin: Segregation of toxocity with the Ah locus. Mol. Pharmacol. 1980, 17, 86-94.

72. Abbott, B.D.; Birnbaum, L.S.; Pratt, R.M. TCDD-induced hyperplasia of the ureteral epithelium produces hydronephrosis in murine fetuses. Teratology 1987, 35, 329-334. [CrossRef]

73. Bryant, P.L.; Schmid, J.E.; Fenton, S.E.; Buckalew, A.R.; Abbott, B.D. Teratogenicity of 2,3,7,8-tetrachlorodibenzo$p$-dioxin (TCDD) in mice lacking the expression of egf and/or TGF- $\alpha$. Toxicol. Sci. 2001, 62, 103-114. [CrossRef]

74. Fujisawa, N.; Yoshioka, W.; Yanagisawa, H.; Tohyama, C. Roles of cytosolic phospholipase $A_{2} \alpha$ in reproductive and systemic toxicities in 2,3,7,8-tetrachlorodibenzo-p-dioxin-exposed mice. Arch. Toxicol. 2018, 92, 789-801. [CrossRef]

75. Jang, J.Y.; Shin, S.; Choi, B.I.; Park, D.; Jeon, J.H.; Hwang, S.Y.; Kim, J.C.; Kim, Y.B.; Nahm, S.S. Antiteratogenic effects of $\alpha$-naphthoflavone on 2,3,7,8-tetrachlorodibenzo-p-dioxin (TCDD) exposed mice in utero. Reprod. Toxicol. 2007, 24, 303-309. [CrossRef]

76. Dragin, N.; Dalton, T.P.; Miller, M.L.; Shertzer, H.G.; Nebert, D.W. For dioxin-induced birth defects, mouse or human CYP1A2 in maternal liver protects whereas mouse CYP1A1 and CYP1B1 are inconsequential. J. Biol. Chem. 2006, 281, 18591-18600. [CrossRef]

77. Abbott, B.D.; Birnbaum, L.S. Effects of TCDD on embryonic ureteric epithelial EGF receptor expression and cell proliferation. Teratology 1990, 41, 71-84. [CrossRef]

78. Choi, S.S.; Miller, M.A.; Harper, P.A. In utero exposure to 2,3,7,8-tetrachlorodibenzo- $p$-dioxin induces amphiregulin gene expression in the developing mouse ureter. Toxicol. Sci. 2006, 94, 163-174. [CrossRef]

79. Miettinen, H.M.; Huuskonen, H.; Partanen, A.M.; Miettinen, P.; Tuomisto, J.T.; Pohjanvirta, R.; Tuomisto, J. Effects of epidermal growth factor receptor deficiency and 2,3,7,8-tetrachlorodibenzo- $p$-dioxin on fetal development in mice. Toxicol. Lett. 2004, 150, 285-291. [CrossRef]

80. Abbott, B.D.; Buckalew, A.R.; DeVito, M.J.; Ross, D.; Bryant, P.L.; Schmid, J.E. EGF and TGF- $\alpha$ expression influence the developmental toxicity of TCDD: Dose response and AHR phenotype in EGF, TGF- $\alpha$, and EGF + TGF- $\alpha$ knockout mice. Toxicol. Sci. 2003, 71, 84-95. [CrossRef] 
81. Harrill, J.A.; Hukkanen, R.R.; Lawson, M.; Martin, G.; Gilger, B.; Soldatow, V.; Lecluyse, E.L.; Budinsky, R.A.; Rowlands, J.C.; Thomas, R.S. Knockout of the aryl hydrocarbon receptor results in distinct hepatic and renal phenotypes in rats and mice. Toxicol. Appl. Pharmacol. 2013, 272, 503-518. [CrossRef]

82. Toivanen, R.; Shen, M.M. Prostate organogenesis: Tissue induction, hormonal regulation and cell type specification. Development 2017, 144, 1382-1398. [CrossRef]

83. Ko, K.; Theobald, H.M.; Peterson, R.E. In utero and lactational exposure to 2,3,7,8-tetrachlorodibenzo- $p$-dioxin in the C57BL/6J mouse prostate: Lobe-specific effects on branching morphogenesis. Toxicol. Sci. 2002, 70, 227-237. [CrossRef]

84. Fritz, W.A.; Lin, T.M.; Moore, R.W.; Cooke, P.S.; Peterson, R.E. In utero and lactational 2,3,7,8-tetrachlorodibenzo- $p$-dioxin exposure: Effects on the prostate and its response to castration in senescent C57BL/6J mice. Toxicol. Sci. 2005, 86, 387-395. [CrossRef]

85. Ricke, W.A.; Lee, C.W.; Clapper, T.R.; Schneider, A.J.; Moore, R.W.; Keil, K.P.; Abler, L.L.; Wynder, J.L.; Lopez Alvarado, A.; Beaubrun, I.; et al. In utero and lactational TCDD exposure increases susceptibility to lower urinary tract dysfunction in adulthood. Toxicol. Sci. 2016, 150, 429-440. [CrossRef]

86. Lin, T.M.; Simanainen, U.; Moore, R.W.; Peterson, R.E. Critical windows of vulnerability for effects of 2,3,7,8-tetrachlorodibenzo-p-dioxin on prostate and seminal vesicle development in C57BL/6 mice. Toxicol. Sci. 2002, 69, 202-209. [CrossRef]

87. Vezina, C.M.; Allgeier, S.H.; Moore, R.W.; Lin, T.M.; Bemis, J.C.; Hardin, H.A.; Gasiewicz, T.A.; Peterson, R.E. Dioxin causes ventral prostate agenesis by disrupting dorsoventral patterning in developing mouse prostate. Toxicol. Sci. 2008, 106, 488-496. [CrossRef]

88. Lin, T.M.; Ko, K.; Moore, R.W.; Simanainen, U.; Oberley, T.D.; Peterson, R.E. Effects of aryl hydrocarbon receptor null mutation and in utero and lactational 2,3,7,8-tetrachlorodibenzo- $p$-dioxin exposure on prostate and seminal vesicle development in C57BL/6 mice. Toxicol. Sci. 2002, 68, 479-487. [CrossRef]

89. Lin, T.M.; Rasmussen, N.T.; Moore, R.W.; Albrecht, R.M.; Peterson, R.E. 2,3,7,8-tetrachlorodibenzo-p-dioxin inhibits prostatic epithelial bud formation by acting directly on the urogenital sinus. J. Urol. 2004, 172, 365-368. [CrossRef]

90. Ko, K.; Moore, R.W.; Peterson, R.E. Aryl hydrocarbon receptors in urogenital sinus mesenchyme mediate the inhibition of prostatic epithelial bud formation by 2,3,7,8-tetrachlorodibenzo-p-dioxin. Toxicol. Appl. Pharmacol. 2004, 196, 149-155. [CrossRef]

91. Schneider, A.J.; Moore, R.W.; Branam, A.M.; Abler, L.L.; Keil, K.P.; Mehta, V.; Vezina, C.M.; Peterson, R.E. In utero exposure to TCDD alters wnt signaling during mouse prostate development: Linking ventral prostate agenesis to downregulated $\beta$-catenin signaling. Toxicol. Sci. 2014, 141, 176-187. [CrossRef]

92. Allgeier, S.H.; Lin, T.M.; Vezina, C.M.; Moore, R.W.; Fritz, W.A.; Chiu, S.Y.; Zhang, C.; Peterson, R.E. WNT5A selectively inhibits mouse ventral prostate development. Dev. Biol. 2008, 324, 10-17. [CrossRef]

93. Schneider, A.J.; Branam, A.M.; Peterson, R.E. Intersection of AHR and wnt signaling in development, health, and disease. Int. J. Mol. Sci. 2014, 15, 17852-17885. [CrossRef]

94. King-Heiden, T.C.; Mehta, V.; Xiong, K.M.; Lanham, K.A.; Antkiewicz, D.S.; Ganser, A.; Heideman, W.; Peterson, R.E. Reproductive and developmental toxicity of dioxin in fish. Mol. Cell. Endocrinol. 2012, 354, 121-138. [CrossRef]

95. Antkiewicz, D.S.; Peterson, R.E.; Heideman, W. Blocking expression of AHR2 and ARNT1 in zebrafish larvae protects against cardiac toxicity of 2,3,7,8-tetrachlorodibenzo-p-dioxin. Toxicol. Sci. 2006, 94, 175-182. [CrossRef]

96. Shiu, W.Y.; Doucette, W.; Gobas, F.A.P.C.; Andren, A.; Mackay, D. Physical-chemical properties of chlorinated dibenzo-p-dioxins. Environ. Sci. Technol. 1988, 22, 651-658. [CrossRef]

97. McCarty, L.S.; Landrum, P.F.; Luoma, S.N.; Meador, J.P.; Merten, A.A.; Shephard, B.K.; van Wezel, A.P. Advancing environmental toxicology through chemical dosimetry: External exposures versus tissue residues. Integr. Environ. Assess. Manag. 2011, 7, 7-27. [CrossRef]

98. Lanham, K.A.; Peterson, R.E.; Heideman, W. Sensitivity to dioxin decreases as zebrafish mature. Toxicol. Sci. 2012, 127, 360-370. [CrossRef]

99. Antkiewicz, D.S.; Burns, C.G.; Carney, S.A.; Peterson, R.E.; Heideman, W. Heart malformation is an early response to TCDD in embryonic zebrafish. Toxicol. Sci. 2005, 84, 368-377. [CrossRef]

100. Plavicki, J.; Hofsteen, P.; Peterson, R.E.; Heideman, W. Dioxin inhibits zebrafish epicardium and proepicardium development. Toxicol. Sci. 2013, 131, 558-567. [CrossRef]

101. Bugiak, B.J.; Weber, L.P. Phenotypic anchoring of gene expression after developmental exposure to aryl hydrocarbon receptor ligands in zebrafish. Aquat. Toxicol. 2010, 99, 423-437. [CrossRef] 
102. Lanham, K.A.; Plavicki, J.; Peterson, R.E.; Heideman, W. Cardiac myocyte-specific AHR activation phenocopies TCDD-induced toxicity in zebrafish. Toxicol. Sci. 2014, 141, 141-154. [CrossRef]

103. Souder, J.P.; Gorelick, D.A. AHR2, but not AHR1a or AHR1b, is required for craniofacial and fin development and TCDD-dependent cardiotoxicity in zebrafish. bioRxiv 2018. [CrossRef]

104. Goodale, B.C.; La Du, J.K.; Bisson, W.H.; Janszen, D.B.; Waters, K.M.; Tanguay, R.L. AHR2 mutant reveals functional diversity of aryl hydrocarbon receptors in zebrafish. PLoS ONE 2012, 7, e29346. [CrossRef]

105. Hofsteen, P.; Plavicki, J.; Johnson, S.D.; Peterson, R.E.; Heideman, W. Sox $9 b$ is required for epicardium formation and plays a role in TCDD-induced heart malformation in zebrafish. Mol. Pharmacol. 2013, 84, 353-360. [CrossRef]

106. Gawdzik, J.C.; Yue, M.S.; Martin, N.R.; Elemans, L.M.H.; Lanham, K.A.; Heideman, W.; Rezendes, R.; Baker, T.R.; Taylor, M.R.; Plavicki, J.S. Sox $9 \mathrm{~b}$ is required in cardiomyocytes for cardiac morphogenesis and function. Sci. Rep. 2018, 8, 13906. [CrossRef]

107. Teraoka, H.; Dong, W.; Ogawa, S.; Tsukiyama, S.; Okuhara, Y.; Niiyama, M.; Ueno, N.; Peterson, R.E.; Hiraga, T. 2,3,7,8-tetrachlorodibenzo- $p$-dioxin toxicity in the zebrafish embryo: Altered regional blood flow and impaired lower jaw development. Toxicol. Sci. 2002, 65, 192-199. [CrossRef]

108. Henry, T.R.; Spitsbergen, J.M.; Hornung, M.W.; Abnet, C.C.; Peterson, R.E. Early life stage toxicity of 2,3,7,8-tetrachlorodibenzo-p-dioxin in zebrafish (Danio rerio). Toxicol. Appl. Pharmacol. 1997, 142, 56-68. [CrossRef]

109. Xiong, K.M.; Peterson, R.E.; Heideman, W. Aryl hydrocarbon receptor-mediated down-regulation of Sox $9 \mathrm{~b}$ causes jaw malformation in zebrafish embryos. Mol. Pharmacol. 2008, 74, 1544-1553. [CrossRef]

110. Watson, A.T.; Planchart, A.; Mattingly, C.J.; Winkler, C.; Reif, D.M.; Kullman, S.W. Embryonic exposure to TCDD impacts osteogenesis of the axial skeleton in Japanese medaka (Oryzias latipes). Toxicol. Sci. 2017, 155, 485-496. [CrossRef]

111. Incardona, J.P.; Collier, T.K.; Scholz, N.L. Defects in cardiac function precede morphological abnormalities in fish embryos exposed to polycyclic aromatic hydrocarbons. Toxicol. Appl. Pharmacol. 2004, 196, 191-205. [CrossRef]

112. Prasch, A.L.; Teraoka, H.; Carney, S.A.; Dong, W.; Hiraga, T.; Stegeman, J.J.; Heideman, W.; Peterson, R.E. Aryl hydrocarbon receptor 2 mediates 2,3,7,8-tetrachlorodibenzo-p-dioxin developmental toxicity in zebrafish. Toxicol. Sci. 2003, 76, 138-150. [CrossRef]

113. Yan, Y.L.; Willoughby, J.; Liu, D.; Crump, J.G.; Wilson, C.; Miller, C.T.; Singer, A.; Kimmel, C.; Westerfield, M.; Postlethwait, J.H. A pair of Sox: Distinct and overlapping functions of zebrafish sox9 co-orthologs in craniofacial and pectoral fin development. Development 2005, 132, 1069-1083. [CrossRef]

114. Garcia, G.R.; Shankar, P.; Dunham, C.L.; Garcia, A.; La Du, J.K.; Truong, L.; Tilton, S.C.; Tanguay, R.L. Signaling events downstream of AHR activation that contribute to toxic responses: The functional role of an AHR-dependent long noncoding RNA (slincR) using the zebrafish model. Environ. Health Perspect. 2018, 126, 117002. [CrossRef]

115. Garcia, G.R.; Goodale, B.C.; Wiley, M.W.; La Du, J.K.; Hendrix, D.A.; Tanguay, R.L. In vivo characterization of an AHR-dependent long noncoding RNA required for proper sox9b expression. Mol. Pharmacol. 2017, 91, 609-619. [CrossRef]

116. Ames, J.; Warner, M.; Brambilla, P.; Mocarelli, P.; Satariano, W.A.; Eskenazi, B. Neurocognitive and physical functioning in the seveso women's health study. Environ. Res. 2018, 162, 55-62. [CrossRef]

117. Mocarelli, P.; Gerthoux, P.M.; Ferrari, E.; Patterson, D.G., Jr.; Kieszak, S.M.; Brambilla, P.; Vincoli, N.; Signorini, S.; Tramacere, P.; Carreri, V.; et al. Paternal concentrations of dioxin and sex ratio of offspring. Lancet 2000, 355, 1858-1863. [CrossRef]

118. Li, M.C.; Chen, P.C.; Tsai, P.C.; Furue, M.; Onozuka, D.; Hagihara, A.; Uchi, H.; Yoshimura, T.; Guo, Y.L. Mortality after exposure to polychlorinated biphenyls and polychlorinated dibenzofurans: A meta-analysis of two highly exposed cohorts. Int. J. Cancer 2015, 137, 1427-1432. [CrossRef]

119. WHO. Assessment of the health risk of dioxins: Re-evaluation of the tolerable daily intake (TDI). In Proceedings of the WHO Consultation, Geneva, Switzerland, 25-29 May 1998; World Health Organization: Geneva, Switzerland, 2000; pp. 1-28.

120. JECFA. Fifty-Seventh Report of the Joint FAO/WHO Expert Committee on Food Additives; Food and Agriculture Organization: Rome, Italy; World Health Organization: Geneva, Switzerland, 2002; pp. 121-146.

(C) 2019 by the authors. Licensee MDPI, Basel, Switzerland. This article is an open access article distributed under the terms and conditions of the Creative Commons Attribution (CC BY) license (http:/ / creativecommons.org/licenses/by/4.0/). 